\title{
The Legal Dimension of Human Rights •
}

\author{
David Kinley
}

Dimensi non-legal yang dimiliki oleh HAM sebagai ekspresi moral dan etika perlu dilegalkan melalui beberapa langkah. Dalam Perspektif hukum Australia ada 3 langkah yang dapat dilakukan (1) merumuskan berbagai pertanyaan dan definisi untuk menjelaskan makna legalisasi HAM serta konsekuensi-konsekuensi yang mungkin timbul atas legalisasi HAM; (2) melakukan penafsiran dan percobaan terhadap implementasi HAM; (3) melakukan implementasi HAM secara legal formal yang dapat memberikan perlindungan dan peningkatan kesejahteraan.

\section{The Significance of Legal and Non-Legal Dimensions of Hu- man Rights}

To a lawyer the title of this chapter might seem odd, implying as it does the existence of other dimensions of human rights. He or she might protest initially that it is surely difficult to conceive of rights, including human rights, in any dimension other than that of legal; and that in any case such nonlegal dimensions as might exist are surely of marginal significance to lawyers. Mor particularly they might suggest that as this book is explicitly concerned with human rights in Australian law there is little or no need for any consideration of dimensions of human rights other than of the legal.
On the face of it these are fair questions, even if rhetorical, as they point to issues that lie at the heart of the debate on law and human rights. It is supposed, what is more, that the concerns upon which these questions are based are not uncommonly raised in one form or another. ${ }^{1}$ Such concerns, however, are at best ill conceived and at worst deceptive. It is the object of this paper to explain why this is so in the process of analysing what constitutes the legal dimension of human rights, both in terms of concept and practice. In short, my aim is to stress the importance of the context in which the law embraces human rights. ${ }^{2}$

Human rights do possess non-legal dimensions and they are amenable to expres-

This article is rewritten with author of Human Rights in Australian Law permission.

'One might, for instance, fairly suspect that Geg Craven's dubbing of the High Court's contextual analysis of implied constitutional rights in Australian as a an exercise in metaphysics", is not to be found without support (even if largely silent) in the legal community: Craven, G, "The High Court of Australia: a Study in the Abuse of Power", Alfred Deakin Lecture (unpublished paper, 1997), p 35.

${ }^{2}$ Such contextual analysis of law is not, of course, novel. Most strikingly perhaps, critical theorists like Stanley Fish attack the notion that law has a formal autonomous existence 
sion in non-legal terms. They may be expressed in moral or ethical term and the obligations they impose are often claimed to operate at the moral level; they have an impact upon and, constitute essential elements of. Most social and cultural orders; and the questions as to their nature form the basis for much that is pursued in political and philosophical endeavour. It is, of course, clear that these dimensions together with the legal dimensions of human rights overlap at the conceptual level, as well as at the level of their practical implementation; though equally it is clear that the degree and significance of such overlap may differ markedly depending on the perspective of the observer.

Within the confiners of this book - seeking as it does, to analyse the place and operation of human rights in the existing Australian legal system - there is no need to establish precisely the boundaries of the various dimensions of human rights, their distinctiveness and the areas in which they intermingle. It is sufficient for the present purpose to accept that the legal dimension of human rights with which this paper is concerned comprises the two basic elements of (i) legal expression - that is in the form of legislative statement or judicial pronouncement, and (ii) the backing of legal sanction - that is, the provision of means by which human rights are or can be enforced and redress provided for any breaches.

Whilst accepting the multi-dimensional nature of human rights, it must be conceded that the most readily apparent expression of human rights is, to lawyers and non-lawyers alike, in legal form; much of their promotion is by way of legal term and the bulk of their implementation through legal means. Indeed, consideration of the law's relationship with any purported human right is necessary, though not alone sufficient, to obtaining an understanding of the human rights:

[T] he issue of whether something is a human right, whether such rights exist or whether people have them, cannot be decided without consideration of the whole range practices, which include recognition in law and governmental maintenance of the claimed ways of acting or being treated. Such practices are ingredient to the very notion of what it is for something to be a human right, ... [t]here is a deep parallelism or, better, a convergence at deep level - between legal rights and human rights. ${ }^{3}$

Human rights expressed in law do not exist in a societal vacuum. Their formulation, enunciation, interpretation, determination, application, enforcement and reform are factors that affect, and are affected by, the wide variety of forces that together constitute any social order. It is then, only through an appreciation of the existence, relative impact and interrelationship of the many dimensions of human rights that one is able to place the legal dimension in perspective and to comprehend its significance for both society at large and the law and legal system in particular.

This paper's contextual analysis of the legal dimension of human rights proceeds by way of three steps. First, the question of the various definitions of human rights is addressed and some conclusions reached

within a social order by exposing the fallacy of such a stance and by insisting upon law's necessarily contingent or contextual existence. Fish, S, there's No Such Think as Free Speech ... and it's a Good Thing Too (Oxford University Press, New York, 1994), especially Chs 11 and 12.

${ }^{3}$ Martin, R, A System of Rights (Clarendon Press, Oxford, 1993), p 87. In addition to legal recognition Martin includes social convention and moral recognition as other "relevant practices". 
as to which of these best explain that part of human rights associated with "the legal". That is followed by an assessment of legally oriented theories of rights and an attempt made to frame human rights in a legal perspective that best suits the form in which human rights are perceived in Australian law and the manner in which they are and might be implemented through the Australian legal system. The third and final step moves away from the theoretical or conceptual level to the practical by focusing on what is, and what can be, the role of the law and the legal system in the "operation" of human rights within the Australian legal order - that is, from their conception, through implementation, to their promotion and enforcement.

The existence as well as the significance of the interrelations between the legal and non-legal dimensions of human rights is apparent throughout the discussions under each of the three substantive sections (relating to the issues of definition, legal perspective, and the role of law and the legal system, respectively) into which the remainder of the paper is divided.

\section{Defining Human Rights}

The theoretical conception of human rights is intimately associated with the enormous body of rights discourse. The salient feature that distinguishes human rights theories from "general" rights theories (or serves to qualify them), is that of their apparent necessary connection with the human condition. What is it that constitutes, or at any rate, is essential to, the state of being human and what social consequences and expectations necessarily flow therefrom are questions the answers to which are beyond the parameters of this paper. However, it is possible to set out the most important factors that mark out the conceptual boundaries of human rights. It is accepted that there is no agreement over the weight that is to be accorded to each, but it can be said that the very depth of the debate and controversy they attract indicates the significance each has played in the perpetual quest to define human rights. 4

\section{Universality of human rights}

The meaning of the universality of human rights is not a settled issue. Indeed, the meaning of universality itself is not a settled issue, ${ }^{5}$ despite the fact that its resolution is logically antecedent to addressing the questions of whether the principle of universality applies to basic human rights, and if so to which ones. The discussion in this section provides only the briefest overview of the debate and no settlement, or even a set of options for settlement, is offered.

The assertion that human rights apply universally to all human beings flows directly from the notion that as a human being one is automatically entitled to respect for one's human dignity. On this basis the object of preserving and promoting the dignity of individual human beings constitutes the central concern of human rights. The coalition of human dignity and the universality of human rights constitutes the bedrock upon which the Universal Declaration of Human Rights (UDHR) was established in 1948. The first words of the Preamble read:

"See generally, Shestack, J, "The Jurisprudence of Human Rights" in Meron, T (ed), Human Rights in International Law: Legal and Policy Issues (Clarendon Press, Oxford, 1984), pp 69-105, and, more recently, by the same author, "The Philosophic Foundations of Human Rights" (1998) 20 Human Rights Quarterly 201.

${ }^{5} \mathrm{~A}$ matter discussed further under "Substantive and Structural Limitations" below. 
Whereas recognition of the inherent dignity and of the equal and inalienable rights of all members of the human family is the foundation of freedom, justice and peace in the world,...

Maurice Cranston, in one of the seminal texts in the area, encapsulates this universality bay declaring that human rights to be "a form of moral right, [though] they differ from other moral rights in being the rights of all people, at all times and in all situations". ${ }^{6}$

Such claims as to the universality of human rights, however, do not go unchallenged. There are forceful arguments that such rights do not inhere in the natural condition of being human (as natural law theorists would have it), 7 nor are they part of a transcendental moral code that is necessary to maintain a base stratum of human dignity (as Kantian rights theorists would have it). ${ }^{8}$ Rather, the existence, or potential existence, of human rights is in general terms culturally dependent, and specifically, their expression and form contingent on the relevant legal order. In other words, prevailing cultural norms will determine what human rights can and do exist, and the legal order will articulate their term and conditions. The human rights that emerge are bestowed upon individuals as a result of the operation of the overlaying social and legal orders, rather than as expressions of innate human characteristics.9 As one commentator puts it:

In its simplest form the cultural relativist criticism asserts that human rights are a Western concept of limited applicability to non-western cultures. Human rights are said to be "Western", not only as a matter of contingent historical fact, but also in their individualistic, ontological implications, ... There seems little point in disputing that the modern concept of human rights has a peculiarly European inheritance. To reach such a conclusion is, of course, not to deny the existence of respect for human values in philosophical and political systems outside Europe, at present or past. ${ }^{10}$

The argument over the cultural relativism of human rights is well illustrated in the continuing debate about the relationship of so-called Asian values with purported universal human rights. It is claimed bay some, for instance, that the importance attached to the maintenance of social order and respect for cultural traditions over that of protection of the rights of individuals within Asian value systems is crucially significant."

${ }^{6}$ Cranston, M, What are Human Rights? (Bodley Head, London, 2nd ed, 1973), p 21.

'See, for example, Finnis, J, Natural Law and Natural Rights (Clarendon Press, Oxford, 1980), Ch 8.

${ }^{8}$ See, for example, Dworkin, R, Taking Rights Seriously (Duckworth, London, 1977), pp 198-99, and, generally, Gerwirth, A, Human Rights: Essays on Justification and Applications (University of Chicago Press, Chicago, 1982).

'See Pollis, A, "Cultural Relativism Revisited: Through a State Prism" [1996] Human Rights Quarterly 316.

"Pritchard, S, "The Jurisprudence of Human Rights: Some Critical Thought and Development in Practice" 91995) 2 Australian Journal of Human Rights 3 at 9. For a general account of human rights and cultural relativism, in respect, inter alia, of Islamic and Asian cultural traditions, see Steiner, HJ and Alston, P, International Human Rights in Context (Clarendon Press, Oxford, 1996), pp 166-255. See also Lee, E, "Human Rights and Non-Western Value" in Davis, M (ed), Human Rights and Chinese Values (Oxford University Press, 1995), p 72.

"The impact that such a concern can have on the twin notions of the universality and invisibility of human rights depends on the degree of its emphasis. According to the Bangkok Declaration on Human Rights (signed by 40 Asian Government on 2 April 1993), for instance, 
An equivalent argument is also raised in developing nations throughout the world, in respect of their concern to advance the process of economic development ahead of guaranteeing individual human rights. ${ }^{12}$

An additional dimension to the challenge to the notion of the universality of human rights posed by differing cultural perspectives stems form the form in which human rights are recognised in any given society and the extent to which they are protected. Thus, in effect, the very existence of a human right or groups of human rights will depend on the nature of a society's governance and the legal order through which it is prosecuted. It is argued that:

Rights have no separate ontological status; they are a by-product of a particular kind of society, one in which the "state" operates constitutionally under the rule of law, is separated from civil society and the 'family', and in which private and public realms are, in principle, clearly demarcated. [In consequence] ... the international regime which attempts on a global scale to promote decontextualised human rights is engaging in a near impossible task.13

This public/private dichotomy points to yet another critical perspective of universality - namely, that provided bay feminist analysis. Feminist scholars argue that the jurisprudence of international law, including and especially international human right law, assumes the universal and neutral application to all states and individuals. "It is not recognized, however, that such principles may impinge differently on men and women; consequently, women's experiences of the operation of these laws tend to be silenced or discounted". ${ }^{24}$ There are gendered disparities in power such that men and women are not usually equal in relation to the human rights they have or can use. ${ }^{15}$ There are two particular systemic

such concern justifies the elevation of the sovereignty of the state above human rights protection (paras $4 \& 5$ ). Whereas to the contrary, both the Bangkok NGO Declaration on Human Rights (adopted on 29 March 1993) and the Asian Charter on Human rights (also an NGOsponsored document; declared on 17 May 1998) insist that state sovereignty must be subordinate to the aim of human rights protection (paras 1,2 \& 4; and 2.5, respectively). For further general discussion, see Ghai, Y, "Human Rights and Governance: The ais Debate" (1994) 15 Australian Yearbook of International Law 1, and Joint standing Committee on Foreign Affairs, Defence and Trade, Improving but ... Australia's Regional Dialogue on Human Rights (AGPS, June 1998), Ch 2.

${ }^{12}$ For a critical assessment of this argument, see Donnelly, $\mathrm{J}$, Universal Human Rights in Theory and Practice (Cornell University Press, Ithaca,1989), Chs 9 and 10. Note that the United Nations Declaration to Development (adopted by the UN General Assembly, under Resolution $41 / 28$, on 4 December 1986), whilst proclaiming the right to development to be a universal and inalienable right, nonetheless stresses the fact that it is also an integral part of fundamental human rights which are interrelated and interdependent (arts 1 (2) \& 6 (2)).

${ }^{13 B r o w n, ~ C, ~ " U n i v e r s a l ~ H u m a n ~ R i g h t s: ~ A ~ C r i t i q u e " ~(1997) ~} 1$ International Journal of Human Rights 41 at 58-59; see also, $\mathrm{Ng}, \mathrm{M}$, "Are Rights Culture Bound?" in Davis, above, n 10, p 59. Some scholars aligned with the so-called Critical Legal Studies movement venture even further claiming that a State's provision for legal mechanisms by which rights may be asserted is contingent on the maintenance of whatever form of societal order that States takes. Rights, in other words, operate as a means by which truly radical political or social change is deflected and deflated. See further, Tushnet, M, "An Essay on Rights" (1984) 62 Texas University Law Review 1363.

${ }^{14}$ Charlesworth, $\mathrm{H}$; Chinkin, $\mathrm{C}$ and Wright, S, "Feminist Approaches to International Law" (1991) 85 American Journal of International Law 595 at 625.

${ }^{15}$ Charlesworth, H, "What are 'women's International Human Rights?", in Cook, RJ, (ed), Human Rights of Women (University of Pennsylvania Press, Philadelphia, 1994), pp 60-62. 
reasons for this. First, the fact of the public sphere orientation of international human rights guarantees women are disadvantaged women as this is not the arena in which customarily they have authoritative presence ${ }^{16}$ And second, the fact that form of freedoms - that is, freedoms from state interference - which has the effect of perpetuating rather than challenging existing power imbalances between men and women. ${ }^{17}$ The freedoms from interference in respect of one's speech, one's religion and religious practice, one's founding of a family, and one's privacy are especially important in this regard.

Evidently then, the philosophical debate that surrounds the conceptual framing of human rights as universal is, and will likely always be, contentious. Yet, to proceed along the path charted for this paper, it is necessary to reach some sort of determination of the issue; to provide, as it were, a working understanding of the principle of human rights' universality. In this respect, one can draw upon the work of Jack Donnelly who, as an advocate of the universality of human rights, maintains that to advance the notion of universality does "not ... argue that human rights are timeless, unchanging, or absolute: any list or conception of human rights - and the idea of human rights itself - is historically specific and contingent". ${ }^{18}$ It is upon such a qualified basis as this that much of the philosophical and jurisprudential debates on human rights can be best understood.

\section{Rights and duties}

The matter of the relationship between rights and duties is crucial to the understanding of the nature and functioning of all rights, ${ }^{19}$ in that for every rights. It is often considered that duties are the "flip side" to rights, in that for every right there is a corresponding duty or obligation namely, to protect, or at least, not to transgress, the right..$^{20}$ As a statement of general principle this can be readily accepted. What, however, it does not tell us is at what point in the existence or exercise of a right does a duty come into play; nor does it indicate upon whom the duty falls. For those of us who are interested in the promotion of human rights through legal mean which, especially if by way of litigation, is so reliant upon the identification of obligation and responsibility, such questions cannot be left unanswered.

One's duty to infringe upon another's human right is not established on account merely of the existence of the right; nor is it necessarily established as a consequence of the right being exercised. It is only at the point where action, inaction or desisting to act is required (whether before, during or after the right-holder's invoking of a right) in order that the right not be infringed upon or curtailed, that the duty becomes apparent. ${ }^{21}$ Thus an individual's right to

${ }^{16}$ See ibid pp 68-71.

${ }^{17}$ See Romany, C, "State Responsibility goes Private: A Feminist Critique of the Public/ Private Distinction in International Human Rights Law" in Cook, above, n 15, pp 92-94.

${ }^{18}$ Donnelly, above, $\mathrm{n} 12, \mathrm{p} 1$, See also Dianne Otto's argument that universality can be seen in a "transformative paradigm", in which the notion is "understood as dialogue, in the sense of struggle, rather than as a disciplinary civilizing mission of Europe ": Otto, D "Rethinking the "Universality' of Human Rights Law" (1997) 29 Columbia Human Rights Law Review 1 at 5.

${ }^{19}$ The issue of the legal implications of this relationship are discussed below, under "Legal Perspectives of Human Rights".

${ }^{20}$ The jurisprudential basis of this notion is discussed below, under "Legal Perspectives of Human Rights".

${ }^{21}$ Whilst a right does not of itself necessarily attract a corresponding duty, it would appear that such a necessary correlation does apply to he obverse. Joseph Raz, for example, proclaims 
privacy need not necessarily attract corresponding duties owned by the state, institutions and other individuals if they all conducted themselves in ways that did not impinge upon the right-holder's enjoyment of that right. It is accepted, however, that in reality those who are able to invade the right to privacy are not so benign, The right places various duties on them to establish prior safeguards against violation of the right (protection of records, and protection of one personal space and bodily integrity; restriction on covert surveillance, and on the collection of information) and to seek to ensure that they are observed at all times (by way of accountability and sanctioning mechanisms), whether or not so requested by the right-holder.

Another important aspect to the right/ duty dichotomy relates to the question of upon whom do duties fall. There is, in this regard, a fundamental difference between the obligations imposed by international human rights instruments and those imposed by domestic laws. International instruments expressly bind the signatory states - that is, the organs through which the states function. Domestic human rights laws, on the other hand, may place obligations of observance on private individuals as well as state organs. This may be the case with certain issue-specific laws - for example, employment and anti-discrimination laws in Australia. ${ }^{22}$ Generic human rights statutes (such as Charters or Bills of
Rights), however, are typically not so broad in their scope, binding only public bodies. ${ }^{23}$

An area of potential development of states' obligation under international law has been opened up in respect of the European Convention on Human Rights 1950 (ECHR). It has been suggested that individuals who under international law have a right of action against the state for its direct actions, may also be able to hold the state indirectly responsible for the activities of other (namely private individuals and other legal persons) within its jurisdiction. In the case of Costello-Roberts $v$ $U K$, the European Court of Human Right declared that as a matter of principle "the State cannot absolve itself from responsibility its obligations to private bodies or individuals". ${ }^{24}$

\section{Structural and substantive boundaries of human rights}

There are certain features of human rights - or at least of their legal expression - that limit the extent of their application. This is so in three principal respects namely (i) the subject matters covered by human rights, (ii) the nature or status of those who claim human rights: and (iii) the conditions imposed on their protection.

\section{Subject matter covered}

The question of the extent of legal coverage of human rights is not easily an-

that "[a] duty is towards a certain person if and only if it is derived from his right"; Raz, J, Ethics in the Public Domain (Clarendon Press, Oxford, 1994), p 43 (p 11).

${ }^{22}$ See $\mathrm{Ch} 9$ (by MacDermott) and $\mathrm{Ch}_{13}$ (by Bailey and Deveruex) in this volume.

${ }^{23}$ This is typically so whether the domestic statute in question is "home-grown' (for example, the United states' Bill of Rights (1791), the Canadian Charter of Rights and Fundamental Freedoms (19820 or the New Zealand Bill of Rights Act 1990), or takes the form of an incorporation of an international instrument (as is the case with the United Kingdom's Human Rights Bill, currently before Parliament, which incorporates the ECHR. The South African Bill of Rights, on the other hand, expressly declares that in addition to all organs of the state it binds any natural or juristic person: $s 8$ of the Constitutions; see further, $n$ 30 below.

${ }^{24}(1995)$ Series A, No 247-C: (1995) 19 EHRR 112, para 27, For further discussion of this case see Clapham, A "The Privatization of Human Rights" (1995) European Human Rights Law Review 20. 
swered. At the level of international law, the answer appears to be straightforward: the coverage extends so far as rights are provided for under all international human rights instruments in force. At the broadest level of human rights categorisation, furthermore, economic, social and cultural rights, and civil and political rights, have equal recognition under the two principal human rights covenants that have flowed from the UDHR and that bear their respective names. ${ }^{25}$ Indeed, recently the equal status of all human rights, and of these two sets of rights in particular, were expressly acknowledge by the vienna Declaration's reiteration of their "universal, indivisible, interrelated and interdependent "nature". ${ }^{26}$

In practice, civil and political rights have almost always been given precedence at both international and domestic levels. Indeed, the neglect ${ }^{27}$ of the protection and promotion of economic and social rights in particular (cultural rights, as we see below, have gained some purchase within traditional human rights is fundamentally challenged. It has been argued, for instance, that the fact of their relative unenforceability at international and domestic levels means that they cannot "be considered as 'real' legal rights". ${ }^{28}$ They are conceived, in this view, as matters that are essentially contingent - their determi- nation being little more than the product of variable policy deliberation,-rather than that of moral necessity or legal principle.

In fact, governments have demonstrate a manifest ambivalence towards such rights. In the international arena they actively promote the equal status of economic, social and cultural rights with civil and political rights, while at home they "fail to take particular steps to entrench those rights constitutionally, to adopt any legislative provisions based explicitly on the recognition of specific economic and social rights as human rights or to provide effective means of redress to individuals or groups alleging violations of those rights". 29

The express provision for rights to a safe environment, housing, health care, food, water and social security, children's welfare, and education in the South African Bill of Rights ${ }^{30}$ is the glaring exception that proves this rule among western democratic states. It is, as yet, too early to assess the justiciability of these rights in South African domestic law. The growing body of academic opinion and speculation is divided on the issue of whether they will be instrumental in delivery of great social justice or whether they will prove to be merely "constitutional ropes of sand". ${ }^{1}$ What, however, transpires from the South African experience over the next decade or so is likely to

\footnotetext{
${ }^{25}$ The International Covenant on Economic, Social and Cultural Rights 1996 (ICESCR) and the International Covenant on Civil and Political Rights 1996 (ICCPR).

${ }^{26}$ The United Nations World Conference on Human Rights, Vienna Declaration and Programme of Action (adopted 25 June 1993), Preamble and para 5.

${ }^{27}$ This is the term used by Philip Alston, "Economic and Social Rights" in Henkin, L and Hargrove, JL (eds), Human Rights: An Agenda for the Next Century (American Society of International Law, Washington DC, 1994), especially pp 151-54.

${ }^{28}$ Vierdag, EW, "The Legal Nature of the Rights Granted by International Covenant on Economic, Social and Cultural Rights" (1978) 9 Netherlands yearbook of International Law 69. at 77; see also, pp 83-94.

${ }^{29}$ Steiner and Alston, above, n 10, pp 256-57.

${ }^{30}$ The "Bill of Rights" comprises Ch 2 of the Constitution of the Republic of South African 1996. The rights indicated are provided by ss 24 and 26-29 of the Constitution.

${ }^{3}$ See, for example, Craig. S and Macklem. P. "Constitutional Ropes of Sand or Justiciable Guarantees? Social Rights in the New South African Constitution" (1992) 141 University of Pennsylvania Law Review 1.
} 
have a profound effect on the future of economic, social and cultural rights in the legal arena, both inside and outside South Africa.

In Australia, substantive economic, social and cultural rights are provided for. Even though such rights terminology may not be readily employed in legislation or public policies, "rights" are provided for through programs and initiatives covering housing and welfare, education, public health care, and clean environment..$^{32}$ Fundamentally, however, these rights are seldom directly inforceable. ${ }^{33}$ Rather, they rely on indirect enforcement through the exercise of the procedural rights bestowed upon individuals bay administrative law. ${ }^{34}$

\section{By whom are human rights exercis- able?}

On the face of it, this question ought to be easily answered: "by human beings, of course". But there are at least two separate perspectives that complicate the issue. The first, and more obvious, is whether all human beings in all circumstances possess human rights and are capable of exercising them. Aside from the continuing debate as to whether and to what extents the unborn, the dead and the insane have human rights, ${ }^{35}$ there is the question of whether groups of persons as well as individuals can claims rights guarantees.

In one sense, it is clear that group rights are provided for in international and domestic guarantees ascribed to individuals against discrimination on group-distinctive grounds such as gender, race, political or philosophical conviction, disability, age or union membership. There are also specific group rights commonly provided for in international human rights instruments and domestic law, relating to cultural activities, minority languages, religious belief and self-determination. These group rights may be exercisable by the group qua group, as well as by its individual members. ${ }^{36}$ The African Charter on Human and Peoples' Rights (1986) ${ }^{37}$ contains such group rights, and the South African Bill of Rights (1996) protects the rights to property of "a person or community" $3^{8}$

The second complicating perspective is singularly legal in that it raises the prospect of redefining the nature of those in whom rights inhere by replacing "human" with the notion of "legal person". The significance of this, of course, lies in the fact

${ }^{32}$ See generally, Bailey, P, "The Right to an Adequate Standard of Living: New Issue for Australian Law" (1997) Australian Journal of Human Rights 25. See also the third periodic report of the Australian Government on the ICESCR, which is Australia's first comprehensive (if uncritical) report to the UN Committee on Economic, Social and Cultural Rights on the conformity of all Australian laws with the Covenant. At the time of writing the submission of the report was imminent.

${ }^{33}$ An obvious exception to this rule in Australian law is that group of rights provided under employment law which accord with art 7 of the ICESCR: see further, Ch 9 by MacDermott in this volume.

${ }^{34}$ See $\mathrm{Ch} 4$ by McMillan and Williams in this volume.

35For discussion see White, AR, Rights (Clarendon Press, Oxford, 1984), pp 75-92.

${ }^{36}$ For a discussion of the conceptual and practical differences between the two usages see Jones, P, Rights (Macmillan, London, 1994), pp 182-87. See also, Triggs. G. "The Rights of Peoples and Individual Rights: Conflict or Harmony?", in Crawford, $J$ (ed), The Rights of Peoples (Oxford University Press, Oxford, 2988), p 141, especially her analysis (on pp 148-50) of Gerhardy $v$ Brown (1985) 159 CLR 70.

${ }^{37}$ Articles 19-24 (which cover rights to equality; self -determination; property; development; security and a safe environment) refer to "all peoples", rather than "everyone" or "all individuals", and declare that the rights are exercisable "individually or collectively"

${ }^{3}$ Section 25; see above, $\mathrm{n} 30$; on the constitutional status of the Bill of Rights. 
that the category of legal persons comprises more than just human beings; it includes, inter alia, corporations, trades unions and many other unincorporated bodies. Legal entities, as distinct from the human beings that comprise them or through whose agency they act, are peculiarly situated in this regard. By their very nature non-human legal persons are unable to exercise, claim or be protected by certain human rights. This is the case, for example, in respect of rights to life, equality, religious and cultural practice. On the other hand, there are other rights that are not necessarily beyond the reach of corporate entities. It is possible to conceive of public and private bodies invoking rights to freedom of expression and movement, and to privacy and fair trial. Out of these, most conspicuously, the right to freedom of expression has been claimed by corporate bodies and been readily condoned by the European Court of Human Rights. ${ }^{39}$ and courts in Canada, ${ }^{40}$ the USA ${ }^{41}$ and Australia.42

Interestingly, there has been relatively little attention paid to the conceptual and practical problem that such claims have on the objects and operation of the legal protection of human rights. The anthropomorphism involved in the extending of human rights to non-human legal bodies can lead to absurdity and inconsistency. In relation to the reasoning employed in the Supreme Court of Canada's decision in Irwin Toy Limited ${ }^{43}$ protecting a corporation's freedom of expression under the Canadian Charter of Rights, Allan Hutchinson observes:

Repeating at length that the law's solicitude for free speech centres upon "individual self-fulfillment and human flourishing" [at 979], whether as an in itself or as a means to truth-finding and democratic participation, the Court managed to overlook the fact that the Irwin Toy company is not human, but only a human creation. ${ }^{44}$

Hutchinson is also critical of the fact that the protection afforded by Charter rights to the actions of corporations is not extended to trades unions in the same way; 45 this he claims to be a sign of the inconsistent application of reasoning to analogous circumstances.

At the international law level, this matter is variously treated. The terms of the right to individual petition under art 25 (1) of the ECHR ${ }^{46}$ refer explicitly to the competence of persons, group of individuals and non-governmental organisations to lodge petitions alleging violation of Convention-protected rights. Under the last mentioned category, the European Commission on Human Rights has accepted petitions from a variety of non-incorpo-

${ }^{39}$ See below, ns 47 and 48 .

${ }^{\circ}$ See Hunter $v$ Southam [1984] 2 SCR 145.

${ }^{42}$ See New York Times.Co v Sullivan 376 US 254 (1964).

42See Australian Capital Television Pty Ltd v Commonwealth (1992) 177 CLR 106 and Nationwide News Pty Ltd $v$ Wills (1992) 177 CLR 1; for discussion; see Ch 3 by Gageler and Glass in this volume.

43Irwin Toy Ltd v Quebec (Attorney-General) [1989] i SCR 927.

${ }^{44}$ Hutchinson, AC, Waiting for Coraf: $A$ Critique of Law and Rights (university of Toronto Press, Toronto, 1995), p 32.

${ }^{45}$ Hutchinson points to the fact that the Supreme Court has insisted that the rights of assembly and association are individual rights not collective rights to be exercised by associations; see for example, Re Public Service Employees Relations Act [1987] 1 SCR 313: 1998 .

${ }^{45}$ Renumbered art 34 upon the coming into effect of Protocol 11 to the ECHR on 1 November 
rated bodies (such as trades unions and private associations) as well as corporations. ${ }^{47}$ Indeed, some of the most celebrated rights of newspaper companies. ${ }^{48}$

On the other hand, under the terms of the right to individual petition under art 1 of the First Optional Protocol to the ICCPR the rights is bestowed only on individuals. As such, corporations, trades unions and other like bodies have had petitions declared inadmissible by the Human Rights Committee. ${ }^{49}$ There appears, however, to be some scope for such bodies to be heard indirectly through petitions lodged by the people "behind" them in their individual capacities as owner or shareholders. ${ }^{50}$

\section{Conditions on protection}

As is clear from the discussion earlier in this section, there are, in terms of the ontology of human rights, widely divergent views as to their universality. However, at the level of their practical implementation or potential, the urgency of the universality debate is less pressing. This is due to a number of factors, among the most important of which are those that relate to the substance of international human rights instruments and the conditions attached to their application..$^{12}$

As regards substance, in the UDHR, the ICCPR and, especially, in the ICESCR, there is express provision for many culturally, philosophically and religiously contingent rights relating, for example, to freedoms of speech; of religion, thought and cultural practices; to found a family; to self-determination; to culturally distinct education; to property rights; and, language rights. Indeed, the very right to equality has to be interpreted in a way that permits differential treatment where appropriate. As judge Tanaka of the International Court of Justice made clear in his seminal (dissenting) judgment in the South West Africa Case (Second Phase):

The principle of ewuality before the law does not mean absolute equality, namely the equal treatment of men without regard to individual, concrete circumstances, but it means the relative equality, namely the principle to treat equally what are equal and unequally what are unequal ...

To treat unequal matters differently according to their inequality is not only permitted but required. ${ }^{.2}$

There is even greater potential for differentiation in interpretation and application of the same human rights, either by domestic courts in the context of their own legal order or by an international body having regard to the legal order of a particular state, provided by the so-called "margin of appreciation" that commonly forms part of the conditions under which rights are protected. For example, allow-

\footnotetext{
${ }^{47}$ For lists of examples and further discussion, see Zwart, T, The Admissibility of Human Rights Petitions (Martinus Nijhoff, Dordrecht, 1994), pp 46-47.

${ }^{48}$ Sunday Times $v$ United Kingdom (No 1) Series A No 30 ( 26 April 1979); Observer and Guardian v United Kingdom Series A No 216 (26 November 1991); and, Sunday Times $v$ United Kingdoms (No 2) Series A No 217 (26 November 1991).

49 See Communications Nos 360/1989 and 361/1989, HRC 1989 Report, pp 308 and 310 , respectively.

${ }^{\circ}$ Zwart, above, n $47, \mathrm{p} 42$.

51There is, in addition, the ultimate qualification of a state avoiding altogether application of a right or rights within its jurisdiction by way of entering a reservation to, or derogation from, the relevant treaty. For a survey and analysis of the use of these devices, see Gardner JP (ed), Human Rights as General Norms and States's Right to Opt Out (British Institute of International and Comparative Law, London, 1997).

${ }^{52}$ [1966] ICJ Rep 6 303-04 and 305. The same rationale is used in the UN's Human Rights Committee's General Comment on Article 26 of the ICCPR: General Comment 18 (1989), paras 7-13.
} 
ance is made under the ICCPR for the limitation of rights "where necessary in a democratic society" or for "the protection of national security or of public order or of public health or morals". 53 Similarly, a discretion akin to that of a margin of appreciation is also extended to state in respect of the "special measures" provisions in the International Convention for the Elimination of All Forms of Racial Discrimination 1965 (CERD) and the Convention on the Elimination of All Forms of Discrimination Against Women 1979 (CEDAW), ${ }^{54}$ in that they permit "appropriate" conditions or qualifications to be placed on the right of formal equality or non-discrimination, in deference to pressing and/or peculiar domestic circumstances, without betraying the essence of the right in question. ${ }^{55}$ Yet, clearly, there is a fine line between claiming a "legitimate" cultural, social or other distinction and the disingenuous use of such a distinction in order to dilute or even avoid the obligation to protect a given hu- man right; especially, that is, when so many of these qualifications to rights are permissible so long as they are considered necessary according to such an ill-defined notion as "a democratic society". It is significant that the judicial and scholastic consideration of such "margin of appreciation" conditions is now sufficiently well developed in respect of the ECHR that the matter has spawned what is fast becoming a distinct sub-category of European rights jurisprudence. This development has important implications in jurisdictions beyond the reach of the ECHR..$^{6}$

The open-endedness of so many fundamental human rights is more generally catered for by the common use of generic "margin of appreciation" statements in the Preambles or opening articles of international human rights instruments; ${ }^{57}$ by the availability of derogation provisions in such instruments; $;^{8}$ and also the 1993 Vienna Declaration. 59

s3See arts 21 and 22, and arts 18 and 19 (as well as art 3), respectively. See also art 4 of ICESCR.

${ }^{54}$ See arts 1 (4) and 2 (2) of CERD and arts 3 and 4 of CEDAW. For a review of the nature and use of special measure provisions under CERD and the corresponding provisions in the Racial Discrimination Act 1975 (Cth), see Pritchard. S., "Special Measures" in Office Commonwealth Race Discrimination Commissioner, The Racial Discrimination Act 1975: A Review (AGPS! Canberra. 1995), especially, pp 190-95.

s5It has been defined in the context of the ECHR as "the freedom to act; manoeuvering breathing or 'elbow' room; or the latitude of deference or error which the Strasbourg organs will allow to national legislative, executive, administrative and judicial bodies, before they are prepared to declare a national derogation from the Convention, or restriction or limita tion upon a right guaranteed by the Convention, to constitute a violation of one of the Convention's substantive guarantees"; Yourow, HC, The Margin of Appreciation Doctrine in the Dynamic of European Human Rights Jurisprudence (Martinus Nijhoff, The Hague, 1996), p 13! ${ }^{5} \mathrm{~S}$ See ibid, generally.

57See, for example, the UDHR, Preamble, which refers to the rights it guarntees as "common standard[s] of achievement", which are to be striven towards "by progressive mea sures"; the ICESDR which obliges States to recognise the rights in the Covenant "to the maxi mum of its available resources ..." (art 2) and permits limitations to rights protection provided they are solely for the purpose of promoting the general welfare in a democratic community" (art 4); and, the use of the essentially subjectively determined command to protect and promote human rights by "appropriates means" throughout art 2 of CEDAW. See also, ICCPRa art 2(2).

${ }^{58} \mathrm{See}$, for example, ICCPR, art 4 (allowing derogation in respect of specified rights in the Covenant in "time of a public emergency"), and ICESCR, art 4 (see previous footnote).

59See above, $\mathbf{n} 26$. While laying stress on the universality and indivisibility of human rights in the Declaration accept that "the significance of national and regional particularities and various historical, cultural and religious backgrounds must be borne in mind ... " (para 5). 
The fact that such limitations and conditions exist is not, it must be emphasised, being challenged. It is likely, in any event, that if they were not expressly provided for in human rights instruments, they would be established in practice by those responsible for implementation and be acknowledged and effectively implied by courts through rules of interpretation. Rather, the concern of the present discussion is simply to establish the fact that human rights cannot be, and, as expressed in legal form are not monolithic or absolute. ${ }^{60}$

It has been evident throughout this general assessment of the defining features of human rights how dependent the concept of human rights is on factors antecedent to law, or determinative of it - for example, moral or philosophical principles or cultural mores. The same is true of those factors that operate at the same level as law or contemporaneously to it - as is the case, for example, with political, social or economic demands and expectations. In the following section, the discussion moves from this fundamental conceptual perspective to consider the specifically legal perspectives of human rights.

\section{Legal Perspective of Human Rights}

In the introduction is was stated that the two base elements of the legal dimension of human rights are their expression in leas terms and the fact that they are backed by legal sanction. A discussion of the mechanisms by which these legal features are bestowed upon human rights is the direct concern of the next section. There remains, however, the preliminary question of at what point in the conceptual formulation of human rights do they become clothed in this legal garb? Or, to put it another way, at what point in the exercise of identifying and articulating human rights is the (or a) legal perspective employed? It is with issues raised by such questions that this section is concerned.

Rights, including human rights, come in many different forms; or at least, they are said to become in many different forms. From a legal perspective, this is an important distinction as it is only those that conform to certain criteria that are capable of being recognised by, or translated into, law, Rights are variously styled as interests, goods, powers, immunities, liberties, claims, demands, "trumps", and entitlements (moral or otherwise); the generic term, it seems. Encompasses many categories. ${ }^{61}$ In addressing these categories, what is at issue is the degree to which they are capable of legal recognition. Each of them, it can be argued, plays, or can play, some role in the legal determination of rights $\mathrm{Per}$ se. Rights as interests or goods or even demands may operate at the level of persuasion in, for example, the policy debate that constitutes part of the process of law-making, rather than by force of their necessary legitimacy ${ }^{62}$ Rights as powers, immunities and even liberties may also operate at the level of persuasion; more usually, however, they constitute the outcome of such policy deliberations, in that they take the form of legal power and prerogatives. Yet, even in this latter form, it is argued, they differ crucially from rights proper.

Hohfeld distinguishes these particular rights manifestations from "true" rights (which are, for him, rights as "claims")

\footnotetext{
${ }^{\circ}$ See further, Australian Law Reform Commission, Multiculturalism and the Law, Report No 57, (AGPS 1992) especially paras $1.15-18$ and $1.25-32$.

${ }^{61}$ For an overview and analysis of the great variety of rights forms, see Jones, above, n 36 , Ch 1 .

${ }^{62}$ For a discussion of the relationship between rights (proper) and right-holders' interests, see Raz, above, n 21, Ch 2.

${ }_{63}^{6}$ Hohfeld, WN, Fundamental Legal Conceptions (Greenwood Press, Westport, 1964), pp 37-38.
} 
labelling them as "privileges" - that is, they are contingently extended to the holder. The contingency in this case is that the body (usually the state) that extends the privilege is under no express Legal obligation or duty to honor or respect the privilege; or to put it another way, the privilege-holder cannot mount any legal demand, nor does he or she possess any legal entitlement, to have the privilege honoured. "A right" according to Hohfeldian reasoning, "is one's affirmative claim of another". ${ }^{64}$ The freedom afforded by such a privilege under this formulation, lasts only as long as no "affirmative claim" is made against it or in contradiction to. it. Upon such a claim being made the privilege immediately evaporates and is replaced by a duty to meet the claim.

The value of Hohfeld's analysis in the present context lies in his exposition of the relationship between rights and duties. Within the matrix of legal concepts that constitutes the basis for his primary work, Hohfeld characterises this relationship as one of a "jural correlative" such that as the imposition of a duty necessarily follows a claimed right, so a right respected is the necessary result of a duty fulfilled. ${ }^{65}$

Many rights theorist agree with this basic line of reasoning that associates rights with duties; indeed, it is fair to say that among legal theorists the principal area of dispute in rights discourse surrounds the questions of the nature of the duty (why is it obligatory?) and its form (what is required to meet it?), rather than the existence of the duty itself. ${ }^{66}$ It is widely accepted that as the correlation of rights with obligations gives rights conceptual authority, so it is the nomination and imposition of obligations within a legal framework that provides rights with practical authority.

The formulation of rights in this manner serves to elevate what might otherwise be merely particular interest, whether individual or group oriented, to a higher plane. It is the case that this result flows primarily from the fact of the transformative effect of legal prescription; ${ }^{67}$ a prescription which itself depends on the putative rights taking the form of claims to which duties are or can be necessarily attached..$^{68}$ From a legal perspective, the significance of this elevation of rights lies in the effect it has on the outcomes in various other social discourses when rights are at issue. It is in this context that Ronald Dworkin's singular characteristion of rights as "trumps" is of particular relevance. "Individual rights" according to Dworkin, "are political trumps held by individuals". ${ }^{9}$ It is, for Dworkin, through the medium of the legal system at large, $7^{\circ}$ that such rights are accorded a superior status to that of mere interests or policy goals (that is, they trump them) on account of their pre-established claims to higher "political morality"."

${ }^{64} \mathrm{Ibid}$, "Introduction", by Wheeler Cook, W, p 9.

65Ibid, pp 35-40.

${ }^{66}$ For-discussion of these points and a survey of relevant literature see Jones, above, $\mathrm{n} 36$, Ch 2, For a through and incisive study of the relationship between legal rights and legal duties see Beatty, D, "Human Rights and Rule of Law" in Beatty, D, (ed), Human Rights and Judicial Review (martinus Nijhoff, Dordrecht, 1994), 1.

${ }^{67}$ On which effect see the following section.

${ }^{68}$ The apparent circularity of this reasoning is a matter of considerable importance and cannot be separated from the instant discussion. The fundamental questions' surrounding the process by which one can distinguish the primacy or legitimacy of some claims over that of other - upon which answer the key to unlock this conundrum depends - were, in respect to human rights, discussed under "Defining Human Rights" above.

${ }^{69}$ Dworkin, above, n $7, \mathrm{p}$ xi.

70Ibid, pp 105-10.

"Ibid, p 9o. See MacCormick, N, Legal Right and Social Democracy (Clarendon Press, Oxford, 1982), Ch 7, for a critical analysis of Dworkin's failure properly to explain this process of the 
The matter of the legal recognition of certain pre-eminent interests or claims as rights, thereby providing a crude order of merit for use within the legal system, is an important feature of the legal prescription of rights. The same matter, however, raises a further problem for rights enforcement. That is, how does one settle disputes arising out of apparent rights conflicts? In respect of some rights regimes, this question can be relatively simply addressed through the establishment by law of priorities between rights, as is the case, for example, in express rights over implied rights in either contract or constitutional law, and in the principle of the paramountcy of children's rights or interests over those of parents, in family law. But in terms of basic human rights the provision of such a hierarchy is not only invidious it is also extremely difficult to establish with any degree of precision, Thus, an additional feature of the legal perspective of human rights, in particular, is that of a conceptual framework within which such rights conflicts can be addressed. It was with this object in mind that Dworkin constructed his so-called Herculean judge model, in which the judge settles such "hard cases" through the application of the cardinal principles that underpin the law, as opposed to the application of politically or socially contingent policies. ${ }^{72}$

Legal positivist, in contrast, argue that such appeals to transcendental legal norms
- no matter, as Dworkin, how subtly to avoid direct reliance on the necessity or moral justification - are neither prescriptive nor descriptive of how the law deals with conflicting rights. The arguments that mount a denial of the necessary correlation of law with morality, like those of HLA Hart and Joseph Raz, ${ }^{73}$ provide an alternative conceptual approach to human rights conflict. Following this reasoning, there is no necessary (moral) hierarchy of right, nor are there immutable legal principles that one can depend upon to settle conflict between rights. Rather, there is the proffered assurance that the mode bay which the conflict can be settled (by legislative provision, court order or administrative direction) is legally or ethically ${ }^{74}$ valid according to the norms of justice that prevail in the relevant society.

Legal theorists like Hart have developed rules for recognising whether a purported law or legal process is legally valid..$^{75}$ Such formulae are generic and apply equally to the legal embracing of human right as to legally recognised human rights as to any other form of rights. What, however, is fundamental to the determination of legally recognised human rights from the perspective of legal positivists is the nature of the underlying theory of justice; it its upon that base that choices are made as to which rights. It is in this respect that Neil MacCormick cogently argues that:

\footnotetext{
justification of rights as trumps; a failure which leads MacCormick to conclude that Dworkin's definition of right is "viciously circular", $p 143$.

${ }^{2}$ Dworkin, above, $\mathrm{n} 8, \mathrm{Ch} 4$, By insisting that the judge appeal to inherent, transcendental legal principles Dworkin maintains that the judge's objectivity is sustained, where it would be lost if he or she was instead to rely upon the social, economic or political policies that prevailed at the relevant time.

${ }^{73}$ Whilst both accept that there often is, as there though to be, a high correlation between legal validity and morality, the two concepts can and do depart from each other. Both theorists talk of morally good laws and morally bad laws, but laws nonetheless: Hart, HLA, The Concept of Law (Clarendon Press, Oxford, 1961), pp 195-207, and Raz, J, "The Rule of Law and its Virtue" (1977) 93 Law Quarterly Review 195 at 198.

${ }^{74}$ See Campbell, Below, n 76.

${ }^{75} \mathrm{Hart}$, ibid, Ch 5.
} 
Men are not born free; yet they are not everywhere wholly in chains; and thus a capital question for the philosophy of law in its critical, if not analytical, modes, is that of attempting to settle what are the forms of social organization which deserve approval as just and well fitted to the human condition and the human situation. To answer the question is to advance a theory of justice. ${ }^{76}$

There is, of course, no articulated theory of justice being advanced in this paper, but it is clear from those who have worked to that end that justice, at both conceptual and practical levels, is not absolute, but rather is always subject to conditions and qualifications. The elemental object of justice for John Rawls, for example. Is that 'all social primary goals liberty and opportunity, income and wealth, and the bases of self-respect - are to be distributed equally". The realisation of this object, however, requires in practice that utilitarian choices be made between competing claims upon these "social primary goals". 7 It is for this reason that Rawls adds the crucial qualification to the above statement, that such an object may be waived without forsaking justice where "an unequal distribution of any or all of these goods is to the advantage of the least favores"..$^{78}$ In this case the challenge for the legal order is, in essence, to provide the rules by which such determinations can be made.

The purpose of this discussion in the context of the aspirations of the present paper is to demonstrate the necessary dependence of the legal perspective of hu- man rights on more fundamental philosophical questions. In result, it is clear of form that facilitate their investment with what may be termed the "force of law". But for those rights that are so amenable, the questions remain as to how such legalisation occurs and with what consequences. It is upon these concerns that the following section is focused.

\section{The Role of Law and Legal System}

That there is an almost unqualified expectation that human rights are to be protected and promoted through law is unsurprising. Evidently this was the assumption of the drafter of the base international human rights instruments. The Preamble to the UDHR, for example, proclaims "that human rights should be protected by the rule of law".79 Indeed, one eminent human rights scholar goes so far as to assert that "giving legal effective force to these rights is the ultimate aim of the struggle for human rights". ${ }^{80}$ The concern of this section is to investigate what this requirement of legal effectiveness means in terms of the operation of the law and legal system in Australia.

For human rights to protected through the rule of law, the twin elements of their being expressed in legal terms and that mechanisms exist for their enforcement, must be present. The legal expression of human rights is not by itself sufficient; enforcement - and, in particular, enforcement by those directly, adversely affected by a breach - must be provided for, Broadly

${ }^{76}$ MacCormick, above, $\mathrm{n} 71, \mathrm{p} 85$. It is this need legitimise, or at least to distinguish between just and unjust social orders, that forms the basis for Tom Campbell's thesis that there is an ethical dimension to legal positivist theory; Campbell, TD, The Legal of Ethical Positivism (Dartmouth, Aldershot, 1996), pp 2-5, 63-73 and 97-101.

7"Rawls, J, A Theory of Justice (Clarendon Press, Oxford, 1972), p 303.

${ }^{78}$ Ibid. Together - the base statement and this qualification - are what Rawls refers to as the "general conception" of his "two principles of justice"; see pp 54-114.

79Third paragraph.

8o Donnelly (1989), above, n 12, p 14. 
speaking the two factors together represent the combined roles of substantive law and legal process in the explication of human rights.

That having been said, the answers to the questions of what precisely constitutes the legal expression and enforcement of human rights, and by what agents these ends are achieved, uncover a more complex picture than might be assumed. The practical (as opposed to conceptual) mechanics of the legal dimension of human rights operate, in reality, in a continuum of interrelated and overlapping processes, sequences and manifestations of human rights propagation. There are, what is more, a number of institutions, both public and private, and sets of sub-systems (Australia's nine jurisdictions and the more or less distinct spheres of the legislature, the executive, the bureaucracy, and the judiciary in each) that all have an impact on the precise form in which the law deals with human rights. Crucially, also, all are open, to greater of lesser extents, to influences that may be related to neither legal nor human rights concerns. It is upon reaching this point that the broad context in which human rights operate becomes most apparent.

It is possible to identify five features of what might be referred to as the "legal expression and enforcement continuum " as it relates to human rights:

- the formulation of human rights

- the articulation and definition of human rights

- the implementation and application of human rights

- the protection and promotion human rights

- the determination of breaches and provision of means for obtaining redress
The full ambit of the legal system's incorporation of human rights is covered bay these features. To provide a comprehensive analysis of what each comprises, of their collective interrelationships, and of the relative and combined impacts of institutions and social forces on their operation is an enormous task. It is sufficient for present purposes to provide an overview of how this matrix of forces and factors operates in practice.

These features or stages of legal process are essentially sequential and their impact upon human rights cumulative, in that the broad objects of the legal expression and enforcement of rights are progressively met as the rights pass through each stage. That having been said, however, it is equally clear that the process is not necessarily linear; they may merge into one another; or the developing law may doubleback to an earlier stage. These characteristics of the legal process are apparent in the following discussion.

\section{Formulation}

The identification and conception of human rights within the law is essentially an exercise in policy analysis, philosophical conviction and, inevitably, political expediency, As such, the functions and operation of the core institutions and processes of government are the most important factors. All three organs of government as well as the bureaucracy (if one chooses not to view it as subsumed under the executive) may be involves in the process, in different ways and to different extents, according to the particular policy at issue.

The impetus for public policy formulation or re-formulation may arise out of the parliamentary or parliamentary committee inquiries, scrutiny, debates or resolutions, ${ }^{81}$ or from judicial developments in

g1Perhaps the most enduring of these processes is that of the pre-legislative scrutiny committees that exist in every Australian Parliament, part of whose function is to scrutinise 
the common law or statutory interpretation, ${ }^{82}$ as well as by way of the more usual and structured channels of executive and "bureaucratic brain-storming". A determination by the executive to sign or ratify a particular international human rights covenant, or to accede to the process of individual petitioning under such a covenant, or to act on a covenant's reporting requirements, ${ }^{83}$ is not only the consequence of policies already in place but these acts themselves contribute to new or further policy initiatives. They might also provide the impetus for general policy statements on human rights issues, ${ }^{84}$ as well as the opportunity for wider public influence to be brought to bear on the policy-making process through consultations with, and the independent actions of, interest groups, lobby groups, other non-government organisations, and individuals. ${ }^{85}$

In term of the concern to secure effective, long-lasting human rights protection and promotion, the single most important stage in the legal process upon which to focus is that of policy formulation. So important is it, ultimately, to win or maintain policy support, that it can fairly be said that

legislative proposals for compliance with broad human rights standards and whose operation regularly involves the committees in discussion (usually informal) with Ministers and departmental policy-makers. For a tabulated survey of the powers and coverage of these scrutiny committees see The Working Party of Chairs of Scrutiny of Legislation Committees throughout Australia, Scrutiny of National Schemes of Legislation. Discussion paper No 1 (AGPS, Canberra, July 2995), para 3.4 For a critique of their operation and an assessment of their potential, see Kinley, D, "Parliamentary Scrutiny of Human Rights: A Duty Neglected?" in Alston, p, (ed), Promotion Human Rights Through Bills of Rights: Comparative Perspectives (Oxford University Press, Oxford, 1998, forthcoming). In respect of the Commonwealth Parliament the Senate's Legal and Constitutional Legislation Committee and its Legal and Constitutional References Committee, and the Human Rights Sub-Committee of the Joint Standing Committee on Foreign Affairs. Defence and Trade, in particular, regularly undertake public inquires into policies and prospective legislative initiatives that impact upon human rights standards in Australia. The Annual Reports of each committee identify and provide brief overview of the matter they have covered.

${ }^{82}$ The landmark 'human rights cases' in various areas of the law discussed in the papers that comprise this book are testimony to the effect that judicial decisions can have on policy thinking Reference, in particular, to the two cases of Mabo v Queensland (No 2) (1992) 175 CLR 1 (in respect of common law development - see Ch 5 by Neilsen and Martin in this volume) and Minister for Immigration and Ethnic Affairs $v$ Teoh (1995) 183 CLR 273 ( in respect of statutory interpretation - see h 4 , by McMillan and Williams and $\mathrm{Ch} 7$, by Crock and Mathew, in this volume) is sufficient to demonstrate how profound that effect can be. For a discussion of the phenomenon in the Canadian context, see Hogg, P and Bushell, AA, "The Charter Dialogue Between Court and legislatures" (1997) 35 Osgoode Hall Law Journal 75.

${ }^{{ }^{3}}$ For a survey (in tabular form) of Australia's reporting obligations to the UN's human rights treaty bodies, see National Action Plan on Human Rights, below, n 82, Appendix D (pp 105-06).

${ }^{84}$ See, for example, the National Action Plan on Human Rights 1994 (and subsequent annual Updates), drawn up by the Department of Foreign Affairs and Trade (DFAR) pursuant to a recommendation of the 1993 Vienna Declaration that National Action Plans be formulated by each state party to the Declaration, The Australian document proclaims that "[t]he universal enjoyment of human rights remains a matter of fundamental importance for Australia. A's such, Australia accords a high priority to the promotion and protection of human rights, both internationally and domestically" (p 3). See also the current Commonwealth Government's In the National Interest 1997 policy statement (also draw up by DFAT) which emphasises the importance to Australia of promoting human rights protection, both within and without its borders, paras 26-31.

${ }^{85}$ The Commonwealth Department of Foreign Affairs and Trade and the Commonwealth Attorney-General's Department both run one or two day human rights policy consultations, two or three times per year, with invited human rights NGOs. 
all the other stages or features of the legal dimension of human rights are essentially. subordinate to this aim. If a supportive policy is in place and its pursuit is being undertaken in earnest then the rest - the legal definition, protection, implementation and curial determination of human rights - will follow. If it is not, in contrast, human rights standards will be diminished or extinguished by the very operation of the law and legal system that reflects such an absent or detrimental policy. The histories of the various anti-discrimination laws in Australian jurisdictions bear out this general point. ${ }^{86}$

\section{Articulation and definition}

The legal articulation of human rights occurs in three principal forms: in statutes; in judgements; and, in administrative rules or regulations. The same human rights may be subject to expression in all three mediums; indeed, almost invariably this is the case as, by the very gravity of their nature, they demand the collective attention of legislators, the judiciary and administrators. The concern for each, in this respect, is to define human rights in some way, whether in terms of their basic nature, scope or application.

A feature of Australia's common law tradition is that there is an onus placed on parliament especially, but also the executive, to endeavour to define legal rights in legislation as fully as possible. This is as true of human rights as of any other form of right. In so doing, legislators may seek directly to define the essence of the right and the legal components of its protection and exercise and limits of its applications. The Privacy Act 1986 (Cth) exemplifies this approach. Additionally, or in the alternative, the right may be indirectly defined by the operation of legislative provisions which, though not mentioning the right itself, effectively delimit it. The boundries of the rights to freedom of speech and movement are established in this manner. ${ }^{87}$

This is not to say, of course, that as a result of the heavily proscriptive form of Australian statues, rights are in fact exhaustively defined. It remains the case that the judiciary plays a vital part in the articulation and definition of legal rights, not just in respect of common law rights not covered by statute, but also, more importantly, in respect of those rights incompletely addressed in legislation. Without exception, legislatively expressed rights fail to anticipate or provide for every circumstance in every detail that might arise in respect of their use or abuse. When such situations lead to litigation, the judiciary may be compelled, or feel itself to be even reformulation of their legislatively provided details. ${ }^{88}$ That is, whether on the provision at issue, ${ }^{89}$ or, where such an intention is unclear or non-existent, to fill the lacuna that would otherwise lead to a perceived injustice.

${ }^{86}$ See $\mathrm{Ch} 13$ by Bailey and Devereux in this volume.

${ }^{87} \mathrm{By}$ way, for example, of the various state and territory defamation laws, the proscription of racial vilification under the Anti-Discrimiation Act 1977 (NSW) and the Discrimination Act 1991 (ACT) and pertinent, implied constitutional limitations on legislative power, in respect of freedom of speech, and the Migration Act 1958 (Cth) and the Australia Citizenship Act 1948 (Cth), in respect of freedom of movement.

${ }^{8 B}$ It is widely accepted that the power to determine existing legal rights constitutes an integral part of the judicial function which falls within the province of judicial power as provided under Ch III of the Australian Constitution; see, for example, discussion of the matter in the judgments in Polyukhovich $v$ Commonwealth (1991) 172 CLR 501. See further, Ch 2, by Sir Anthony Mason and $\mathrm{Ch} 3$ by Gageler and Glass, in this volume.

${ }^{89} \mathrm{By}$ consulting such sources as the second reading speeches of the legislation in question, and relevant reports of parliamentary inquiries and law reform commissions under $S$ is $A B$ of the Acts Interpretation Act 1901 (Cth). 
In respect of human rights law this is apparent from the judiciary's impact upon the meaning and extent of anti-discrimination laws ${ }^{90}$ and immigration law ${ }^{91}$ which are in the main detailed in legislation, as much as its role in the development of the constitutional right to free political speech $^{92}$ and the right to a fair trial ${ }^{93}$ which are hardly detailed at all in legislation. It is also evident in respect of legislation the principal purpose of which though not centered on human rights, nonetheless incidentally affects the meaning of human rights standards. 94

Certainly, then, the primary, or at least initial, responsibility for the legal articulation and definition of human rights lies with the parliament and executive: inevitably, however, further definition is provided by the judiciary.

\section{Implementation and application}

Once human rights have been identified and defined in law, it is incumbent upon the state to ensure that their terms are implemented generally and as specific instances demand. It is principally through the administrative departments under the policy and political direction of ministers individually and the executive collectively, on the one hand, and the courts on the other, that these functions are fulfilled. The rights to privacy, to vote, to own property, to be free from discrimination, unwarranted detention, restrictions in speech or political conviction or religious belief, as well as all the legitimate qualifications to these rights, require a substantial administrative and dispute settlement structure if they are to be delivered to individuals in a complex society like Australia.
The fulfillment of these functions in intimately associated with the objects of the protection and promotion of human rights through legal mean.

\section{Protection and promotion}

The very processes of the policy formulation, legal definition, implementation and application of human rights establish the basis for their protection and promotion. Thereby, the means are provided by which human rights breaches may be prevented or at least limited, and where infringements do occur, the process for the imposition of sanctions is set in place and mechanisms are made available to individuals to seek redress before courts and tribunals. The obligation to ensure human rights guarantees in law are honoured in promise as well as practice falls, in the main, on the state. This is clearly the case where the relevant legal obligations expressly bind the state alone - as is the case in the areas of immigration, administrative, privacy and criminal laws. The burden, however, also rests with the state, albeit indirectly, where legal strictures bind private legal actors - as is the case with family law and anti-discrimination laws in Australia. The state, by operation of its organs of government, in other words, is always, ultimately responsible for the protection and promotion of human rights.

The responsibilities of the parliament, the executive, and to a limited extent the judiciary, are, as we have seen, largely strategic in kind; those of the bureaucracy (including such agencies as the police and tribunals) and the judiciary are more particular on account of being more situation-specific. In addition, the duties of protection and promotion are discharged by way of a

\footnotetext{
${ }^{\circ}$ See $\mathrm{Ch} 13$ by Bailey and Devereux in this volume.

'See $\mathrm{Ch} 7$ by Crock and Mathew in this volume.

${ }^{92}$ See Ch 3 Gageler and Glass in this volume.

${ }^{93}$ See $\mathrm{Ch} 6$ by Bronitt and Ayers in this volume.

${ }^{94} \mathrm{As}$, for example, with nascent information technology legislation; see $\mathrm{Ch} 11$ by Arup and Tucker in this volume
} 
number of "satellite" public bodies such as the Commonwealth's Human Rights and Equal Opportunity Commission and the State' Anti-discrimination Boards and Equal Opportunity Commissions under their respective empowering statutes. ${ }^{95}$ For not only do these bodies typically possess dispute settlement powers, they also invariably have more general preventive roles. ${ }^{96}$ Inquiries into particular human rights issues; community wide and groupspecific education programs; scrutiny and analyses of government policies, and ongoing communication with interested and affected parties are all essential parts of human rights protection and promotion. Ombudsman offices, law reform bodies and legal aid commissions are also important to the fulfillment of these ends, through the indirect, but essential, concerns of their respective functions.

Outside the realm of government, some NGOs, including and especially Community Legal Centers, play a significant and direct role in the promotion of human rights laws throughout the community. Some also, more indirectly, assist in the protection of human rights, by way of exerting pressure on governments to amend policies or laws by extending their protective or enabling reach, or by removing impediments to the enjoyment of rights.

\section{Determination of breaches and redress}

The process of determining whether there has been an infringement of a legally protected human right in particular instances, as with all legal rights, is essentially judicial in character. In the Australian context, this means that courts at all levels address disputes concerning laws affecting human rights, in respect of all matters within and without federal jurisdiction, ${ }^{97}$ although the High Court has ultimate authority to make such determinations under the terms of $\mathrm{Ch}$ III the Constitution..$^{8}$

The redress that a successful litigant may obtain from the courts accords with what remedies are available to the courts as regards the right in question. Such a statement may seem obvious and somewhat simplistic, but the importance within common law jurisdictions of the existence of a cause of action and a concomitant remedy cannot be overestimated. Together they comprise the essential elements of enforcement by way of litigation of all rights, including human rights. Indeed, in a comparative analysis of the differing common law world "one has no 'rights' unless one is protected by a cause of action", and that, in consequence, "the point of departure for any legal action is the existence of a wrong, not that of a right". ${ }^{99}$

Tribunals, and similar administrative or quasi-judicial bodies, may also have determinative and remedial powers. The extent of these powers varies from jurisdiction to jurisdiction, with the tribunals in the federal sphere being barred from making final determinations under the separation of powers doctrine, ${ }^{100}$ while those in the States

95For details and discussion see $\mathrm{Ch} 13$ by Bailey and Devereux in this volume.

${ }^{96}$ The HREOC is guided in this respect by the inclusion of major international anti-discrimination and human rights instruments (including the ICCPR) that relate to the Commission's functions in the Schedules to the Human Rights and equal Opportunity Commission Act 1986 (Cth).

${ }^{97}$ Which, following Kable v Director of Public Prosecutions (NSW) (1996) 189 CLR 51, may encompass much more of what was once thought to be the preserve of state jurisdiction; see further $\mathrm{Ch} 2$, by Sir Anthony Mason and $\mathrm{Ch} 3$, by Gageler and Glass, in this volume.

${ }_{98}^{8}$ See Polyukhovich v Commonwealth (1991) 172 CLR 501.

${ }^{99}$ Legrand, P, "European Legal Systems are not Converging" (1996) 45 International and Comparative Law Quarterly 52 at 70-71. He notes that, in contrast, "[ $\mathrm{t}]$ he focus of the national civil codes is ... on rights with the law of actions having been confined to 'technical' (and in the legal community's mind, secondary) codes of procedure": ibid.

${ }^{100}$ As made clear in Brandy $v$ Human Rights and equal Opportunity Commission (1995) 183 CLR 245; see, for further discussion, $\mathrm{Ch} 2$ by Sir Anthony Mason, $\mathrm{Ch} 13$ by Bailey and Devereux, and $\mathrm{Ch} 14$ by Eastman and Ronalds in this volume. 
suffer no such barriers. ${ }^{101}$ Notwithstanding the fact the decisions of all such bodies, irrespective of jurisdiction, are subject to judicial review, the decisions made by tribunals are clearly significant in terms both of numbers of disputes settled and the effective setting of standards of human rights observance..$^{102}$

In fulfilling these functions tribunals and, more especially, courts operate at a number of levels within the broad ambit of the practical legal dimension of human rights that is the concern of this section of the paper. At the most immediate level, the determination of a dispute concerning legally protected human rights constitutes the basis for settlement of the dispute. In addition, however, it may represent the culmination and protection, ${ }^{103}$ or a lesser combination of those stages. ${ }^{104}$

'It is only after a review, such as that undertaken in this section, that of all the nominated stages in the legal system's dealing with human rights, that the system's fully integrated nature in this regard becomes most apparent, its form better understood, and the significance of both these perspectives best appreciate.

\section{Conclusions - The Significance of Context}

Two themes run through this paper. The first reiterates the importance of the legal dimension of human rights - that is, the legal expression and enforcement of human rights - to the object of securing their observance and advancement. The second is built around the phenomenological point that such legal protection of human rights necessarily exists within, and is vitally affected by, a broader, non-legal context: The whole process of the law's interaction with human rights is contextually situated from the manner in which human rights are conceived in legal terms to the consequences of an arbitral determination that there has been a breach of their terms.

Patently, the legal dimension of human rights is but one dimension. For anyone to focus on it, to the willful or unconscious neglect of all else, is to fail fully or even adequately to appreciate the nature of human rights and their role in our social order. For lawyers to do so is to diminish their practice of the law and to squander potential. A fuller appreciate of the place of human rights within a legal system, their origins and the factors that continue to influence them, not only permits their more effective pursuit through the means provided by that legal system, it also inspires debate and change within broader social and political spheres. ${ }^{105}$ The part then, that can be played by those who seek to advance the cause of human rights through law is significant indeed.

${ }^{10}$ For a comparative analysis in the context of anti-discrimination bodies in Australia, see $\mathrm{CH} \mathrm{13,} \mathrm{by} \mathrm{Bailey} \mathrm{and} \mathrm{Devereux} \mathrm{in} \mathrm{this} \mathrm{volume.}$

${ }^{102}$ See Ch 4 by McMillan and Williams in this volume.

${ }^{103}$ The common law right of native title, as established in the Mabo (No 2) (992) 175 CLR 1, is emblematic in this regard.

${ }^{104}$ The tentative steps taken by the judiciary in identifying and articulating human rights in the areas of information technology (see $\mathrm{Ch} 11$ by Arup and Tucker in this volume) and health law (see Ch 12 by Freckelton and Loff in this volume) provide examples of such combination.

ros See Charlesworth, H, "The Australian Reluctance about Rights", in P Alston (ed), Towards an Australian Bill of Rights (Centre for International and Public Law. Canberra, 1994), pp 49-51, and Sarkin, J, "The Role of the Legal Profession in the Promotion and Advancement of Human Rights Culture" (1995) 21 Commonwealth Law Bulletin 1306. 